Иркутский государственный университет, г. Иркутск, Российская Федерация

Ю. В. Борисова

Иркутский государственный университет, 2. Иркутск, Российская Федерация

Е. В. Чигрина

Байкальский государственный университет, г. Иркутск, Российская Федерация С. В. Корнакова

Байкальский государственный университет, г. Иркутск, Российккая Федераиия

\title{
ПРАВОВЫЕ И СОЦИАЛЬНО-ЭКОНОМИЧЕСКИЕ ПРОБЛЕМЫ ТЕРРИТОРИАЛЬНОГО РАЗВИТИЯ: НАЛОГОВЫЙ АСПЕКТ
}

АНнотАцИЯ. В статье рассмотрены основные правовые и социально-экономические проблемы территориального развития в рамках налоговой составляющей: нестабильность налогового законодательства, проблема отбора налогоплательщиков и формирования налоговой культуры жителей Иркутской области, проблема неравномерного распределения налогов по уровням бюджетной системы, проблема с урегулированием споров между налоговыми органами и налогоплательщиками; проблема ориентации налогового контроля в первую очередь на фискальную функцию без учета социальных, экономических и иных факторов. Проанализирована эффективность налогового администрирования на территории Иркутской области, выявлены причины невзыскания налогов в бюджет региона, рассмотрены угрозы для пополняемости бюджета, предложены направления увеличения доходов бюджета территории через повышение качества налогового администрирования, что предполагает наличие установленных законодательно правил взимания налогов и стимулов в налоговом процессе, кроме того предполагается наличие экономического анализа и прогнозирования налоговых поступлений.

кЛючЕВЫЕ слОВА. Налоговое администрирование; территориальные проблемы; налоговый контроль; налоговая проверка; бюджетная эффективность.

ИНФОРМАЦИЯ О СТАТЬЕ. Дата поступления 18 сентября 2017 г.; дата принятия к печати 19 декабря 2017 г.; дата онлайн-размещения 29 декабря 2017 г.

L. N. Batyanova Irkutsk State University, Irkutsk, Russian Federation

Yu. V. Borisova Irkutsk State University, Irkutsk, Russian Federation

Ye. V. Chigrina

Baikal State University, Irkutsk, Russian Federation

S. V. Kornakova Baikal State University, Irkutsk, Russian Federation

\section{LEGAL AND SOCIO-ECONOMIC PROBLEMS OF TERRITORIAL DEVELOPMENT: THE TAX ASPECT}

ABSTRACT. The article considers the main legal and socio-economic problems of territorial development in terms of the tax component: the instability of the tax

\section{Baikal Research Journal}


legislation, the problem of selecting taxpayers and forming the tax culture of Irkutsk Oblast residents; the problem of uneven distribution of taxes by levels of the budget system, the problem of settling disputes between tax authorities and taxpayers; the problem of the tax control orientation to the fiscal function in the first place, without taking into account the social, economic and other factors. The effectiveness of tax administration on the territory of Irkutsk Oblast is analyzed, the reasons for non-collection of taxes to the regional budget are identified, the threats to replenishment of the budget are considered, the directions for increasing budget revenues through improving the quality of tax administration are proposed, which suggests the existence of statutory rules for collecting taxes and incentives in the tax process. That is, the presence of economic analysis and forecasting of tax revenues is assumed.

KEYWORDS. Tax administration; territorial issues; tax control; tax audit; budget efficiency.

ARTICLE INFO. Received September 18, 2017; accepted December 19, 2017; available online December 29, 2017.

Любое государство нуждается в денежных средствах для обеспечения своей полной функции. Одним из главных образующих финансовых источников для государства являются средства, которые собираются с физических и юридических лиц. Этими обязательными сборами, осуществляемыми с помощью государственного законодательства, являются налоги.

Налоговая система представляет собой важнейший экономический институт, благодаря которому определяется процветание общества и государства. Повышение эффективности налогового администрирования является одной из самых главных задач в сфере налогообложения в государстве в целом, и на отдельных территориях, в частности [1, с. 20].

В текущих экономических условиях национальной экономики органам государственного и муниципального управления как никогда сложно добиваться эффективных результатов в своей деятельности.

По нашему мнению, ряд проблем налогового администрирования в России, которые до сих пор не получили решения значительно понижают потенциал собираемых налогов, увеличивают затраты ресурсов на проведение налоговых проверок и усложняет получение налоговых доходов государством.

В условиях экономического кризиса одним из немногих способов увеличения доходов бюджета является повышение качества налогового администрирования. Следовательно, налоговым органам в настоящее время необходимо уделять намного больше внимания совершенствованию налогового администрирования, которое будет являться основным инструментом актуального обеспечения полноты государственного бюджета [2, с. 274].

Для решения этих проблем необходимо рассматривать такие пути совершенствования налогового администрирования на уровне государства в целом и на уровне муниципалитетов, в частности, как: применение горизонтального мониторинга; поддержку обмена информацией между ведомствами налоговых инспекций; повышение доверия налогоплательщиков; развитие института досудебного аудита.

Затрагивая современные территориальные проблемы налогового администрирования в России, конечно же нельзя обойти вниманием проблему доверия. Государство, принимающие участие в налоговых отношениях выступает как властный субъект, имеющий огромный комплекс властных полномочий, недоступных налогоплательщику. Поэтому, формируя налоговую политику, нельзя забывать о доверии налогоплательщиков, которое может достаточно быстро исчезнуть, что и происходит в последние 20 лет. Отношение населения к налоговым органам

\section{Baikal Research Journal}

электронный научный журнал Байкальского государственного университета 
постоянно ухудшается, попытки модернизации и оптимизации воспринимаются населением как негативные действия [3, с. 64].

Государство прорабатывает множество проблем, но почти не вспоминает о самом главном - налогоплательщиках. Невозможно создать доверие населения на основе поправок в законы, для доверия нужны долгие годы работы, при которой ни бизнес, ни государство не обманывают друг друга [4]. Государству необходимо воспитывать у населения высокую налоговую культуру, а также установить доверительные и надёжные взаимоотношения с налогоплательщиками.

Существует необходимость в формировании доверительных отношений между налогоплательщиком и налоговыми органами, для достижения данной потребности производится работа по поиску новых видов и способов работы с налогоплательщиками. Примером такого способа можно назвать внедрение в начале 2010 года мобильных офисов налоговой службы. Это позволило налоговым специалистам выезжать в отдаленные населенные пункты, что, очевидно, увеличило зону контроля налоговой службы, а также упростило процесс взаимодействия с налоговыми службами для самих жителей отдаленных населенных пунктов [5, с. 113].

Нельзя оставлять без внимания то, что из-за недоверия усугубляется еще одна проблема - наличие большого количества разногласий между налогоплательщиками и налоговыми органами. Заинтересованность государством и бизнесом в создании действенного способа по урегулированию споров очевидна. Глава ФНС М.В. Мишустин отмечает, что Федеральная Налоговая Служба радикально изменила подходы к процедурам банкротства, вследствие чего число принятых решений о признании должника банкротом снизилось в 2.6 раза в 2016 году, а сумма погашенной задолженности в ходе дел о несостоятельности в 1 полугодии 2016 года выросла более чем в два раза и составила 31 млрд. рублей. Благодаря выработке единой правовой позиции на стадии досудебного урегулирование удалось снизить количество судебных споров с бизнесом в 1 полугодии 2016 года на 3,2 \% по сравнению с аналогичным периодом 2016 года [6].

Проблема доверия налогоплательщиков так же становится более актуальной при упоминании горизонтального мониторинга, как инструмента эффективного налогового администрирования, который развивает качественно новые взаимоотношения с налоговыми органами и налогоплательщиками. Используя успешный иностранный опыт, ФНС начинает практику горизонтального мониторинга, представляющего собой процедуру, при которой заключается специальное соглашение о надзоре между налоговой службой и налогоплательщиком. Данное соглашение заключается на добровольной основе, предусматривает сотрудничество, раскрытие информации налоговому органу налогоплательщиком, предварительное согласование условий налогообложения сложных сделок, а также снижение последующего бремени контроля налоговой службой [7, с. 95].

Интеграция современных информационных технологий позволяет ФНС намного более качественно решать задачи, связанные с передачей новых функций, таких как создание Реестра субъектов малого бизнеса, Реестра ЗАГС, ФИАС. Кроме того, ФНС России совместно с ФТС России активно прорабатывают внедрение информационных ресурсов ведомств. Так с 1 января 2017 года налоговые органы наделены полномочиями по администрированию страховых взносов. В настоящее время Служба проводит работы по организации информационного взаимодействия с государственными внебюджетными фондами [4].

Эффективное развитие налогового потенциала территории тесно связано с налоговым администрированием, осуществляемым на этой территории. В рамках данного исследования рассмотрим особенности и основные проблемы на-

\section{Baikal Research Journal}

электронный научный журнал Байкальского государственного университета 
логового администрирования в Иркутской области на примере деятельности межрайонной инспекции Федеральной налоговой службы № 20 по Иркутской области.

Согласно исследованию итогов ее работы за 2016 год, в консолидированный бюджет Российской Федерации поступило 23708873 тыс. руб. налогов и сборов, что составляет 16,4 \% в общих поступлениях УФНС по Иркутской области, и больше на 4295264 тыс. р. или 122,1 \% по сравнению с аналогичным периодом прошлого года (19 413609 тыс. р.). Следовательно, методы и инструменты, используемые данной инспекцией, являются эффективными и актуальными.

Собираемость налогов и сборов за 2016 год составила 96,23\% . Причинами не абсолютной собираемости налогов и сборов, явилось расхождение между начисленной и уплаченной суммой в размере 919426 тыс. р. (начислено 24628343 тыс. р., уплачено 23708917 тыс. р.)

В бюджеты территорий поступило 21781924 тыс. р., что на 6068674 тыс. p. или в 1,4 раза больше по сравнению с прошлым годом (15 712327 тыс. р.) В федеральный бюджет поступило 1926949 тыс. р., что на 1774333 тыс. р. или в 1,9 раза меньше по сравнению с уровнем доходов за 2015 год (3 701282 тыс. р.) (рис. 1).

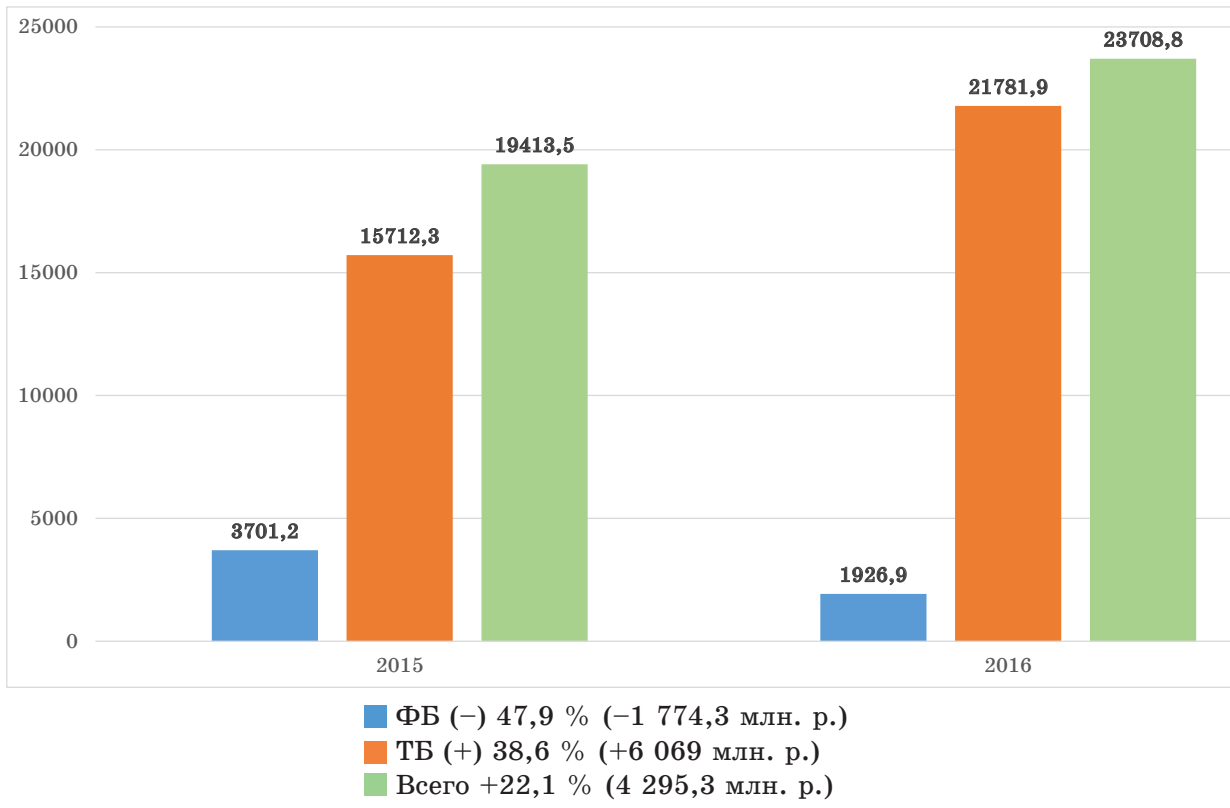

Рис. 1. Поступления налогов и сборов в бюджетную систелу Российской Федерации МИФНС России по ИО за 2015-2016, ллн. $p$.

Индикативные показатели поступлений налогов и сборов в федеральный бюджет, доведенные до инспекции в размере 1445205 тыс. р., выполнены за 2016 год на 132,4 \%. Фактические доходы федерального бюджета составили 1926949 тыс. р. (рис. 2).

\section{Baikal Research Journal}




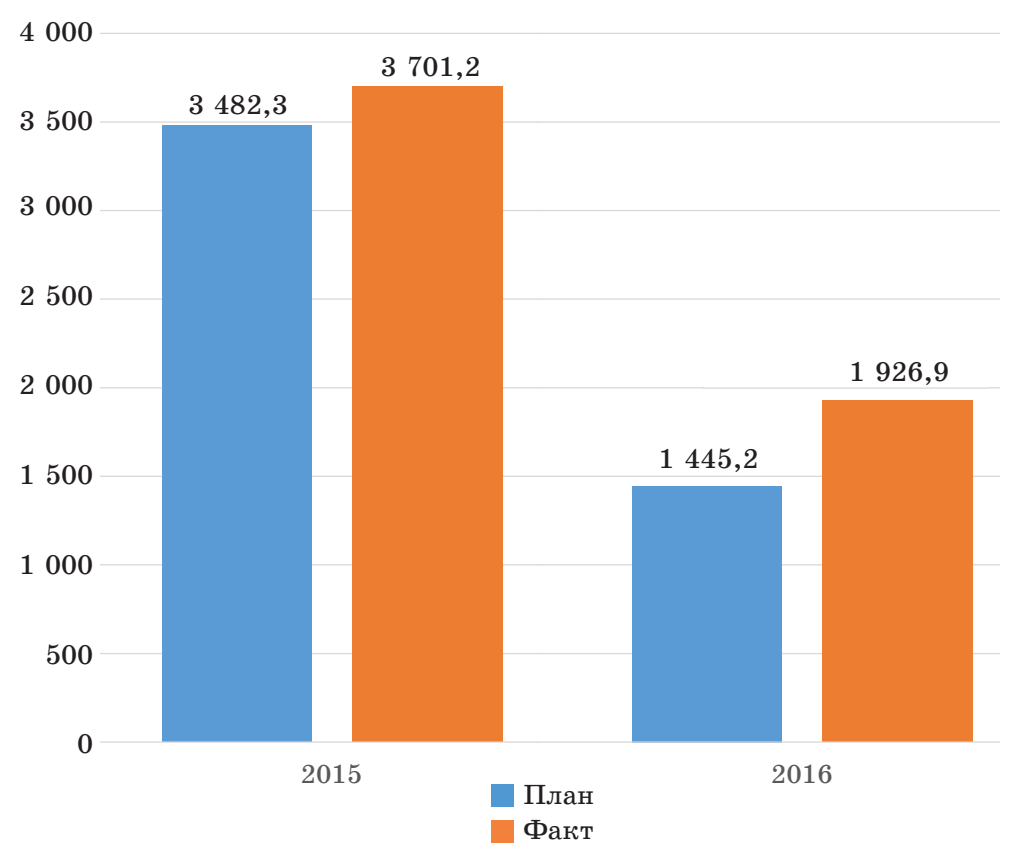

Рис. 2. Выполнение индикативных показателей в Федеральный Бюджет по МИФНС России по ИО за 2015-2016 г2., млн р.

Перевыполнение индикативных показателей за 2016 год на сумму 481744 тыс. р. или на 32,4 \% произошло в основном за счет перевыполнения НДС на сумму 182490 тыс. р. или на 69,3 \% и по налогу на прибыль на сумму 189940 тыс. р. или на $37,5 \%$.

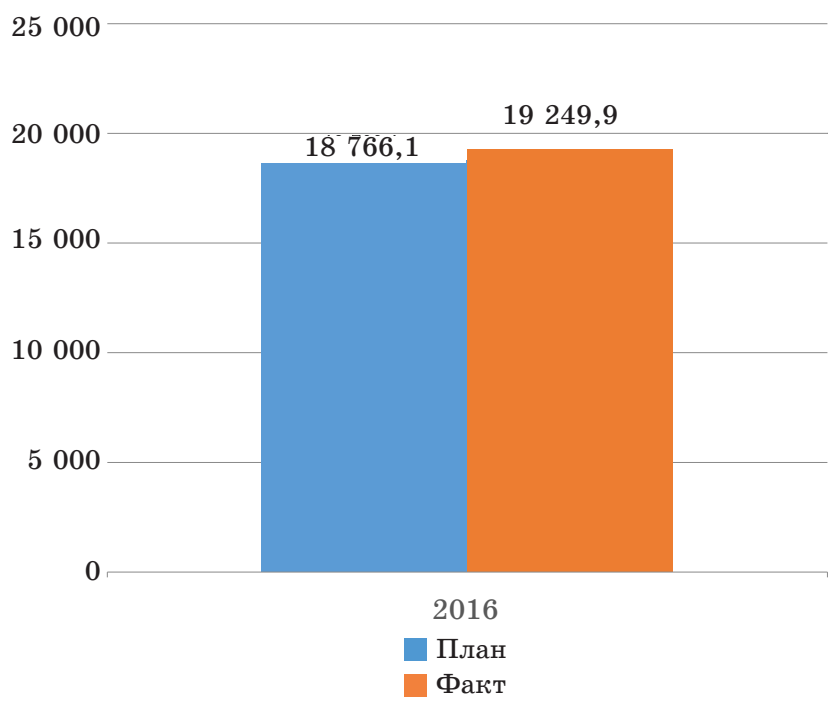

Рис. 3. - Выполнение индикативных показателей в областной бюджет инспекиией за 2016 г., мллн $р$.

\section{Baikal Research Journal}


Задание по мобилизации платежей в областной бюджет, доведенное до инспекции в размере 18766100 тыс. р., выполнено за 2016 год на 102,6\%. Фактические доходы областного бюджета составили 19249865 тыс. р. (рис. 3).

Иркутская область продолжает нести одни из максимальных в стране потерь бюджета в результате установления на федеральном уровне льгот по региональным налогам. Федеральные льготы по налогу на имущество организаций по итогам 2015 года составили 5532 млн р., что является 11 по величине значением среди субъектов РФ.

Из вышесказанного следует, что на современном этапе налогового администрирования в Иркутской области осуществляется продуктивная работа налоговых инспекций, так, на примере приведенных статистических данных можно с уверенностью сказать о способности выполнять налоговыми органами цели и поставленные перед ними задачи, что в свою очередь характеризует эффективность налогового администрирования в Иркутской области.

Далее представлено исследование по контрольной работе, проведенной налоговыми органами области в разрезе межрайонной инспекции Федеральной налоговой службы № 20 по Иркутской области.

По результатам контрольной работы, дополнительно начислено в бюджеты всех уровней с учетом налоговых санкций и пени 1121000 тыс. р., в том числе по выездным проверкам 968627 тыс. р., по камеральным проверкам - 42623 тыс. р., по результатам прочих контрольных мероприятий и пени, начисленных в КРСБ за несвоевременную уплату налогов, взносов и сборов - 109750 тыс. р.

Сумма поступивших (взысканных) платежей без учета сумм, поступивших по решениям других налоговых органов из сумм доначисленных платежей составляет 315385 тыс. р., удельный вес поступивших (взысканных) платежей в общей сумме дополнительно начисленных платежей в отчетном периоде сложился в размере $28,1 \%$. В том числе по проверкам предыдущих периодов 133926 тыс. р. или $42,5 \%$, по проверкам отчетного периода 181459 тыс. р., или 57,5\% всех поступивших платежей.

Сумма невзысканных платежей на отчетную дату по налоговым проверкам, составляет 939541 тыс. р., или 83,8 \% от суммы доначислений.

Основные причины невзыскания:

1. Решения не вступили в законную силу на сумму 496588 тыс. р. (52,9 \%);

2. Недоплачено в связи с отсутствием денежных средств 138293 тыс. р. (14,7 \%);

3. Приостановлено взыскание по решению суда на сумму 57872 тыс. р. (6,1 \%);

4. Срок уплаты по требованиям не наступил на сумму 13998 тыс. p. (1,5 \%);

5. Снятие налогоплательщиков с налогового учета в связи с изменением местонахождения на сумму 17864 тыс. p. $(1,9 \%)$;

6. Введена процедура банкротства - 179538 тыс. р. (19,1\%);

7. Прочие причины составили 27092 тыс. р., или $2,9 \%$.

Обеспечительные меры приняты в отношении 16 налогоплательщиков, (из 33 оконченных ВП) на общую сумму 435593 тыс. р.

В структуре задолженности по состоянию на 01.01.2017 г. 86,3 \% (1 318752 тыс. p.) приходится на группу федеральных налогов, 6,7 \% (101 778 тыс. р.) - на долю региональных, 4,3 \% (65 893 тыс. р.) - на местные налоги и сборы и 2,5 \% (38 024 тыс. р.) на налоги со специальным налоговым режимом.

По состоянию на 01.01.2017 г. по категориям налогоплательщиков задолженность распределятся следующим образом: задолженность бюджетных учреждений -1668 тыс. p. $(0,1 \%)$, задолженность организаций и индивидуальных предпринимателей, находящихся в процедуре банкротства 448507 тыс. р. $(29,3 \%)$, задолженность отсутствующих должников, в отношении которых судом

\section{Baikal Research Journal}


отказано в возбуждении процедуры банкротства - 125846 тыс. p. (8,2 \%), задолженность физических лиц - 126772 тыс. p. (8,3 \%), задолженность остальных налогоплательщиков - 823690 тыс. p. (53,9\%).

В результате контрольной деятельности по категориям налогоплательщиков задолженность распределятся следующим образом: задолженность бюджетных учреждений -149 тыс. p. $(0,1 \%)$, задолженность организаций и индивидуальных предпринимателей, находящихся в процедуре банкротства 345437 тыс. р. $(55,6 \%)$, задолженность отсутствующих должников, в отношении которых судом отказано в возбуждении процедуры банкротства - 71131 тыс. p. $(11,5$ \%), задолженность остальных налогоплательщиков - 204211 тыс. p. $(32,9$ \%).

Из вышеперечисленного следует вывод, что наблюдается снижение задолженности по федеральным налогам на 131510 тыс. р. $(9,1 \%)$, по налогам со специальным налоговым режимом на 13211 тыс. p. (25,8 \%) [8].

Основной прирост задолженности наблюдается:

1) по региональным налогам на 17805 тыс. p. (21,2\%)

2) по местным налогам на сумму 30577 тыс. р. $(86,6 \%)$

Причины прироста задолженности:

1) неоплата платежей, доначисленных по контрольной работе - 336893 тыс. р. $(34,3 \%)$;

2) неоплата текущих начислений -505634 тыс. р. (51,4 \%) ;

3) принято задолженности из др. налогового органа - 64462 тыс. p. (6,6 \% );

Одновременно на снижение задолженности повлияло ряд факторов:

1) добровольное погашение задолженности, имеющейся по состоянию на 01.01.2016 в размере 140809 тыс. р. $(9,6 \%)$;

2) уменьшено по декларациям в размере 11800 тыс. p. (1,1\%);

3) взыскание задолженности в размере 110927 тыс. р. (10,2\%);

4) списание задолженности безнадежной к взысканию, а также непогашенной за счет конкурсной массы, после вынесения определения Арбитражного суда Иркутской области о завершении конкурсного производства в размере 714900 тыс. p. $(65,4 \%)$;

5) погашено отсроченной задолженности по решению ФНС в сумме 47628 тыс. p. $(4,4 \%)$;

6) миграция налогоплательщиков в размере 65107 тыс. p. (6,0 \%).

Показатели эффективности:

1. Снижение объема задолженности по налогам и сборам к объему поступлений по налогам и сборам - 5,95\% (план по СМС и коллегии УФНС не более $13 \%)=10$ баллов.

2. Общая эффективность взыскания - 57,87 \% (план по коллегии УФНС и концепции - $75 \%$ ).

3. Эффективность взыскания по имущественным налогам ФЛ $-70,7 \%$ (план по коллегии УФНС и концепции - 75 \%).

4. Эффективность взыскания по НДФЛ физических лиц - 94,2 \% (план по коллегии УФНС и концепции - $75 \%$ ).

5. Эффективность по контрольной работе (поступления от доначислений) 40,6 \% (план по коллегии УФНС и концепции - 70 \%, план по СМС - более $70 \%)=1$ балл.

6. Эффективность по контрольной работе (поступления от задолженности) 53,6 \% (план по коллегии УФНС и концепции - 40 \%, план по СМС - более $60 \%)=4$ баллов.

7. Эффективность исполнительских действий по ст. 47 НК РФ - 33,4 \% (план по коллегии УФНС и концепции $-45 \%$, план по СМС $-33 \%$ ) = 5 баллов.

\section{Baikal Research Journal}

электронный научный журнал Байкальского государственного университета 
8. Эффективность исполнительских действий по ст. 48 НК РФ - 78,8 \% (план по коллегии УФНС и концепции - 70 \% ) [9, с. 30].

Осуществление главных целей налоговой политики в Иркутской области реализуется через механизм налогового администрирования, это предполагает наличие установленных законодательно правил взимания налогов и стимулов в налоговом процессе, кроме того предполагается наличие экономического анализа и прогнозирования налоговых поступлений [10, с. 212].

Кроме того, стоит отметить, что на основании приказа ФНС России от 20.12.2016 № ММВ-7-4/693 принято решение о переименовании ИФНС России по Правобережному округу г. Иркутска в Межрайонную ИФНС России № 20 по Иркутской области и реорганизации путем присоединения Межрайонной ИФНС России № 3 по Иркутской к Межрайонной ИФНС России № 20 по Иркутской области, в состав подведомственных территорий которой отнесены Правобережный округ г. Иркутска, г. Бодайбо, Бодайбинский и Мамско-Чуйский районы. Это свидетельствует о попытках эффективной реорганизации и оптимизации процессов налогового администрирования в регионе [11].

Таким образом, роль камеральных налоговых проверок в области безусловно растёт [12, с. 33]. Благодаря увеличению правового охвата налоговых органов региона значительно повысилась результативность подобных проверок. Несмотря на это, согласно исследованию деятельности налоговых органов области, сумма дополнительно начисленных платежей по результатам камерального контроля 2016 год составила 42623 тыс. р., что ниже аналогичного показателя прошлого года на 14575 тыс. р.

Снижение суммы начисленных платежей по результатам камеральных проверок объясняется снижением объема доначислений по камеральным проверкам налоговых деклараций по НДС.

Основная сумма доначислений приходится на проверки налоговых деклараций по НДС - 20590 тыс. руб., что составляет 48,37 \% от общей суммы доначислений, 26,28 \% или 11189 тыс. р. приходится на доначисления по налогу на прибыль, 8,6\% или 3647 тыс. р. приходится на доначисления по НДПИ, 3,58 \% (1527 тыс. р.) составляют доначисления по ЕНВД, и незначительные суммы доначислений приходится на оставшиеся налоги: земельный налог, УСН, транспортный налог и налог на имущество) [5, с. 114].

В целом можно дать положительную характеристику реализации налогового администрирования в области. Из приведенных данных можно сделать вывод, что благодаря камеральным и выездным проверкам достигаются большие поступления в бюджеты всех уровней. Кроме того, әффективность обуславливается снижением задолженности по налогам и сборам к объему поступлений по налогам и сборам. Несмотря на это эффективность взыскания не достигла установленного планом уровня, поэтому можно обозначить, что в сфере эффективности взыскания необходимо проводить мероприятия для улучшения данной отрасли. Так же снизилась сумма начисленных платежей по результатам камеральных проверок по причине снижения объема доначислений по камеральным проверкам налоговых деклараций по НДС. Всё это говорит в первую очередь о том, что налоговое администрирование в Иркутской области имеет ряд проблем, ключевой из них является несовершенство системы законодательного и нормативного регулирования статуса крупнейших налогоплательщиков, определение описываемой категории отсутствует в принципе. Из этого происходит проблема иного рода: камеральные проверки крупных компаний не имеют отличий от проверок других категорий налогоплательщиков, объективность применяемых к ним методик оценки результативности выездных налоговых проверок встает под вопрос.

\section{Baikal Research Journal}

электронный научный журнал Байкальского государственного университета 
Необходимо сказать, что сам процесс налогового администрирования самых прибыльных налогоплательщиков в регионе формируется с помощью подзаконных актов ФНС России и Министерства финансов, данные акты достаточно часто изменяются, что привносит путаницу среди налогоплательщиков, потому что порой просто невозможно отследить все изменения.

При проведении контрольных проверок для налогового органа области встает серьезная проблема отбора налогоплательщиков, с которыми будут проводиться контрольные мероприятия. Как правило, в группу наиболее подверженную выездным проверкам попадают такие организации: имеющие проблемы с неточностью предоставленных данных; организации с более чем тремя расчетными счетами; организации с отличием показателя результативности проведенного анализа от установленного предельного значения по отрасли; так же речь идет про организации, которые вовремя или систематически не предоставляют отчетность.

Кроме всего в поле зрения часто попадают налогоплательщики с неоднократными нарушениями налогового законодательства. Необходимость налогового контроля в Иркутской области в большей степени определяется степенью уклонения от уплаты налогов. Часто, случаи уклонения от уплаты налогов налогоплательщиками происходят из-за неведения бухгалтерского учета или ведения при нарушении регламентированного порядка (отсутствие налоговой базы у данных налогоплательщиков вызывает дополнительные сложности для проверочных работ налоговых органов региона) [11].

Ограничивают рост собственных доходов консолидированного бюджета региона и планы Правительства Российской Федерации по централизации доходов субъектов Российской Федерации от налога на прибыль по ставке один процент с последующим направлением указанных доходов на поддержку наименее обеспеченных регионов, к которым Иркутская область не относится.

Важно понимать, что фискальный подход в вопросе организации налогового контроля не является единственным, однако в региональной налоговой политике прослеживается именно подобная тенденция.

Для Иркутской области, как и других регионов особенно остро стоит проблема нехватки бюджета субъекта, в первую очередь. это обусловлено неравномерным распределением налогов по уровням бюджетной системы. Наибольшая часть налоговых поступлений уходит в федеральный бюджет.

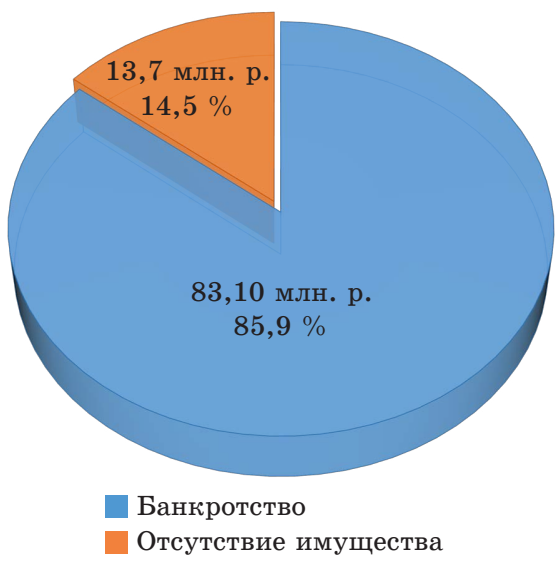

Рис. 4. Причины непоступления доначисленных налоговыли органали платежей

\section{Baikal Research Journal}


На данный момент основными угрозами для пополняемости областного бюджета являются:

1) централизация в федеральном бюджете 1 \% на прибыль (потеряется порядка 2,1 млрд р. в следствие централизации доходов 1 \% налога на прибыль с последующим направлением указанных доходов на поддержку наименее обеспеченных регионов, к которым Иркутская область не относится);

2) уменьшение с 88 до 57-62 \% норматива зачисления акцизов на нефтепродукты в бюджет области, в следствие чего регион теряет порядка 2,1 млрд р. при сохранении действующего в 2016 году норматива;

3) благодаря III этапу реализации налогового маневра около 1 млрд р. потеряет областной бюджет в результате корректировки формулы расчета показателя, характеризующего особенности добычи нефти при определении величины НДПИ. В рисунке 5 приведена катастрофическая тенденция налоговой отдачи региона в федеральный бюджет.

Достаточно частым делом для арбитражных судов является рассмотрение налоговых споров - это заметно затрудняет работу налоговых органов в Иркутской области, стоит отметить, что зачастую решение данных споров не убирает разногласия между сторонами полностью. Это приводит к конфликту между сторонами, кроме того это служит источником недоверия со стороны населения к налоговой службы.

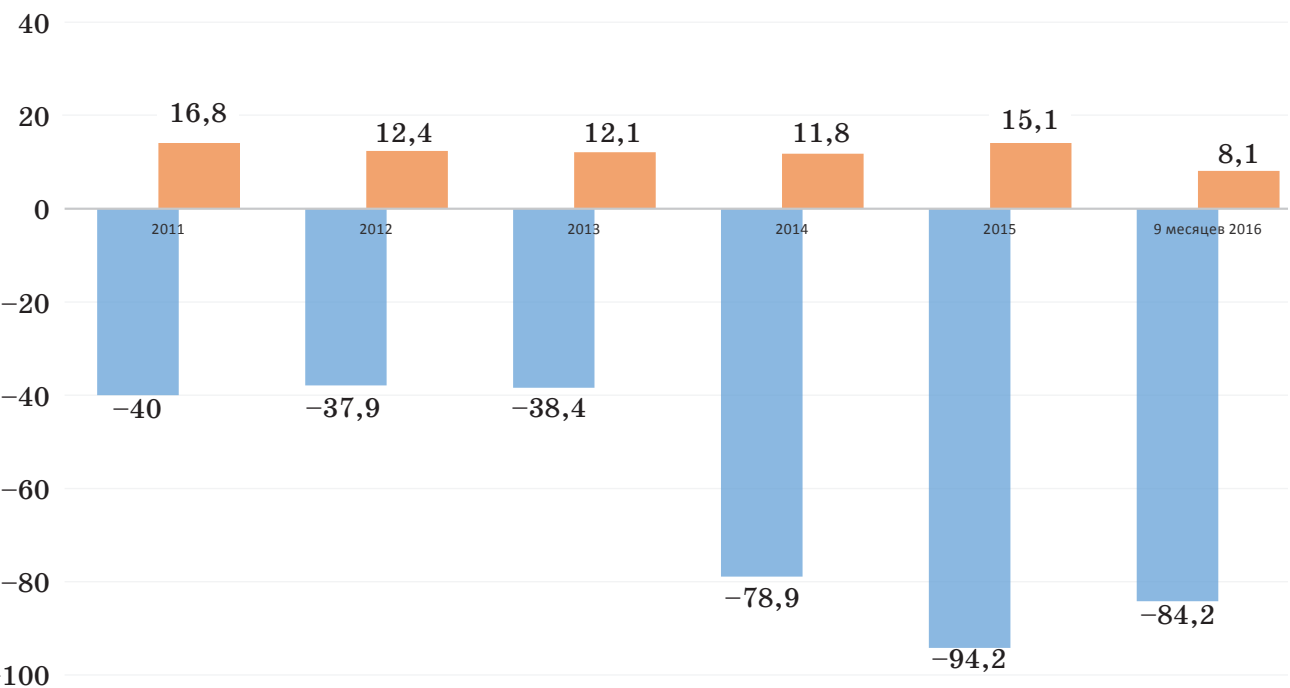

Мобилизовано налогов с территории Иркутской области в федеральный бюджет

Перечислено Иркутской области МБТ из федерального бюджета (за искл. субвенций)

\section{Рис. 5. Налоговая отдача региональной эконолики для федерального бюджета (млрд р.)}

В последние годы произошел серьезный скачок в эффективности налоговых проверок в Иркутской области благодаря применению процедуры предпроверочного анализа. Однако именно аналитическая функцию наиболее трудно развивать для налоговых органов, так как речь идет о работе с огромным количеством данных.

Наиболее актуальным для Иркутской области в плановом периоде будет являться вопрос перехода к налогообложению исходя из кадастровой стоимости

\section{Baikal Research Journal}


имущества физических лиц и отдельных объектов недвижимости, определенных статьей 378.2 Налогового кодекса Российской Федерации [1, с. 30].

Переход к налогообложению имущества физических лиц исходя из кадастровой стоимости осложнен ввиду высокой инвентаризационной стоимости недвижимости в регионе. Так, по итогам 2014 года инвентаризационная стоимость одного объекта налогообложения налогом на имущество физических лиц составила 547 тыс. р., что является пятым по величине значением среди регионов страны [8, с. 42].

Для целей актуализации налогооблагаемой базы физических лиц в 2016 году Правительством Иркутской области проводилась переоценка кадастровой стоимости объектов недвижимости жилого и нежилого фондов. Однако, применимость ее результатов в связи с принятием на федеральном уровне решения о введении моратория на проведение кадастровой оценки или переоценки до 2020 года будет осложнена (Федеральный закон от 3 июля 2015 года № 360-Ф3 «О внесении изменений в отдельные законодательные акты Российской Федерации»).

Таким образом, одной из серьезных проблем для региона является нестабильность налогового законодательства, кроме того перед налоговыми органами стоит проблема отбора налогоплательщиков и формирования налоговой культуры жителей Иркутской области. В рамках бюджетной политики как инструмента налогового администрирования в Иркутской области так же стоит отметить проблему неравномерного распределения налогов по уровням бюджетной системы [13, с. 40]. Так же в области существует проблема с урегулированием споров между налоговыми органами и налогоплательщиками. Одной же из самых острых момент на данный момент является проблема ориентации налогового контроля в первую очередь на фискальную функцию без учета социальных, экономических и иных факторов.

\section{Список использованной литературы}

1. Ефремова Т. А. Налоговое администрирование в России: предпосылки становления и особенности функционирования / Т. А. Ефремова // Финансы и управление. - 2013. № 2. - C. 1-23. - DOI: 10.7256/2306-4234.2013.2.622.

2. Борисова Ю. В. Проблемы социального воспроизводства и развития в Прибрежненском МО Братского района Иркутской области / Ю. В. Борисова, А. В. Копылов // Социальная консолидация и социальное воспроизводство современного российского общества: ресурсы, проблемы, и перспективы : материалы III всерос. науч.- практ. конф. / под ред. О. А. Кармадонова, О. А. Полюшкевич. - Иркутск : Изд-во ИГУ, 2017. - С. 271-274.

3. Борисова Ю. В. Влияние малого бизнеса на социально-экономическое развитие России / Ю. В. Борисова // Трансгрессия социокультурного пространства : материалы V всерос. науч. конф. / под ред. О. А. Эдельштейн, О. А. Полюшкевич. - Иркутск : Изд-во ИГУ, 2016. - С. 58-65.

4. Мишустин М. В. Налоговой службе удалось сохранить положительный тренд налоговых поступлений [Электронный ресурс] / М. В. Мишустин // ФНС России. - М., 2017. - Режим доступа: https://www.nalog.ru/rn77/ news/activities_fts/6170491/ (дата обращения: 18.03.2017).

5. Прибылова Ю. А. Актуальные проблемы налогового администрирования и пути их решения / Ю. А. Прибылова // Актуальные проблемы налоговой политики : сб. ст. / отв. ред. Е. В. Шередеко, С. А. Халетская. - Иркутск : Изд-во ИрГУПС, 2016. - Ч. 2. C. $111-115$.

6. М. В. Мишустин выступил на парламентских слушаниях по основным направлениям налоговой политики на 2016-2018 годы [Электронный ресурс] // ФНС России. - М., 2017. - Режим доступа: https://www.nalog.ru/rn39/ news/activities_fts/5601056/ (дата обращения: 18.03.2017).

7. Анисимов А. Л. Проблема толкования и применения основных принципов налогового законодательства Российской Федерации: экономико-правовой аспект / А. Л. Анисимов // Известия Уральского государственного экономического университета. - 2014. № 3 (53). - C. 91-96.

\section{Baikal Research Journal}

электронный научный журнал Байкальского государственного университета 
8. Проскура Е. П. Эффективность налогового администрирования: понятие и содержание / Е. П. Проскура // Современные технологии управления. — 2013. — № 7 (31). C. $34-43$.

9. Абрамчик Л. Я. Налоговое администрирование в системе финансового контроля / Л. Я. Абрамчик // Финансовое право. - 2015. - № 6. - С. 28-30.

10. Гоголев А. М. Современное состояние и проблемы развития налогового администрирования / А. М. Гоголев // Публичное и частное право. — 2014. — № 3. - С. 211-216.

11. Светлана Бондарчук: поступления налогов на имущество в консолидированные бюджеты субъектов РФ выросли за 2016 год на 5\% [Электронный ресурс] // ФНС России. M., 2017. - Режим доступа: https://www.nalog.ru/rn38/news/activities_fts/6712877/ (дата обращения: 18.03.2017).

12. Васильева Н. В. К вопросу о формах и методах налогового контроля / Н. В. Васильева // Академический юридический журнал. - 2013. - № 2. - С. 31-35.

13. Горева А. С. Проблемы налогового администрирования в России / А. С. Горева // Аспирант. - 2015. - № 13. - С. 37-40.

\section{References}

1. Efremova T. A. Tax administration in Russia: Preconditions of Formation and Features of Functioning. Финансы и управление $=$ Finansy $i$ upravlenie $=$ Finance and Management, 2013, no. 2,. pp. 1-23. DOI: 10.7256/2306-4234.2013.2.622. (In Russian).

2. Borisova Yu. V., Kopylov A. V. Problems of Social Reproduction and Development in Pribrezhnensky Municipal Formation of Bratsk District of Irkutsk Oblast. In Karmadonov O. A., Polyushkevich O. A. (eds). Sotsial'naya konsolidatsiya $i$ sotsial'noe vosproizvodstvo sovremennogo rossiiskogo obshchestva: resursy, problemy, i perspektivy. Materialy 3 vserossiiskoi nauchno-prakticheskoi konferentsii [Social Consolidation and Social Reproduction of Modern Russian Society: Resources, Problems and Prospects. Materials of International Research Conference]. Irkutsk State University Publ., 2017, pp. 271-274. (In Russian).

3. Borisova $\mathrm{Yu}$. V. Influence of small business on social and economic development of Russia. In Edelshtein O. A., Polyushkevich O. A. (eds). Transgressiya sotsiokul'turnogo prostranstva. Materialy 3 vserossiiskoi nauchno-prakticheskoi konferentsii [Transgression of sociocultural space. Materials of International Research Conference. Materials of International Research Conference]. Irkutsk State University Publ., 2016, pp. 58-65. (In Russian).

4. Mishustin M. V. Tax service has managed to maintain a positive trend in tax revenues. Available at: https://www.nalog.ru/rn77/ news/activities_fts/6170491/. (In Russian).

5. Pribylova Yu. A. Topical problems of tax administration and ways of their solution. In Sheredeko E. V., Khaletskaya S. A. (eds). Aktual'nye problemy nalogovoi politiki [Topical Problems of Tax Policy]. Irkutsk State University of Railway Engineering, 2016, vol. 2, pp. 111-115. (In Russian).

6. M. V. Mishustin spoke at the parliamentary hearings on the main directions of the tax policy for 2016-2018. Available at: https://www.nalog.ru/rn39/news/activities_fts/5601056/. (In Russian).

7. Anisimov A. L. The problem of interpretation and application of basic principles of tax legislation of the Russian Federation: economic and legal aspect. Izvestiya Ural'skogo gosudarstvennogo ekonomicheskogo universiteta = Journal of the Ural State University of Economics, 2014, no. 3 (53), pp. 91-96. (In Russian).

8. Proskura E. P. Efficiency of tax administration: concept and content. Sovremennye tekhnologii upravleniya = Modern Management Technology, 2013, no. 7 (31), pp. 34-43. (In Russian).

9. Abramchik L. Ya. Tax administration in financial control system. Finansovoe pravo = Financial Law, 2015, no. 6, pp. 28-30. (In Russian).

10. Gogolev A. M. Current condition and problems of development of tax administration. Publichnoe $i$ chastnoe pravo $=$ Public and Private Law, 2014, no. 3, pp. 211-216. (In Russian).

11. Bondarchuk S. Proceeds of property taxes in consolidated budgets of constituent entities of the Russian Federation increased by 5\%. Available at: https://www.nalog.ru/rn38/ news/activities_fts/6712877/. (In Russian).

12. Vasileva N. V. On the question of forms and methods of tax control. Akademicheskii yuridicheskii zhurnal = Academic Law Journal, 2013, no. 2, pp. 31-35. (In Russian).

\section{Baikal Research Journal}


13. Goreva A. S. Problems of tax administration in Russia. Aspirant, 2015, no. 13, pp. 37-40. (In Russian).

\section{Информация об авторах}

Батьянова Людлила Николаевна - кандидат философских наук, доцент, кафедра государственного и муниципального управления Институт социальных наук Иркутский государственный университет, 664003, г. Иркутск, ул. К. Маркса, 1.

Борисова Юлия Владилировна - кандидат экономических наук, доцент, кафедра государственного и муниципального управления Институт социальных наук Иркутский государственный университет, 664003, г. Иркутск, ул. К. Маркса, 1, e-mail: julia661@mail.ru.

Чигрина Елена Владимировна - кандидат экономических наук, доцент кафедры теории государства и права и социально-правовых дисциплин Байкальский государственный университет, 664003, г. Иркутск, ул. Ленина, 11, e-mail: ChigrinaEV@bgu.ru.

Корнакова Светлана Викторовна - кандидат юридических наук, доцент кафедры уголовного права, криминологии и уголовного процесса Байкальский государственный университет, 664003, г. Иркутск, ул. Ленина, 11.

\section{Authors}

Lyudmila N. Batyanova - PhD in Philosophy, Associate Professor, Chair of Public and Municipal Administration, Institute of Social Sciences, Irkutsk State University, 1 K. Marx St., 664003, Irkutsk.

Yulia V. Borisova - PhD in Economics, Associate Professor, Chair of Public and Municipal Administration, Institute of Social Sciences, Irkutsk State University, 1 K. Marx St., 664003, Irkutsk; e-mail: julia661@mail.ru.

Yelena V. Chigrina - PhD in Economics, Associate Professor, Chair of Theory of State and Law and Socio-Legal Disciplines, Baikal State University, 11 Lenin St., 664003, Irkutsk; e-mail: ChigrinaEv@bgu.ru.

Svetlana V. Kornakova - PhD in Law, Associate Professor, Chair of Criminal Law, Criminology and Criminal Procedure, Baikal State University, 11 Lenin St., 664003, Irkutsk.

\section{Для цитирования}

Батьянова Л. Н. Правовые и социально-экономические проблемы территориального развития: налоговый аспект / Л .Н. Батьянова, Ю. В. Борисова, Е. В. Чигрина, С. В. Корнакова // Baikal Research Journal. - 2017. - T. 8, № 4. - DOI : 10.17150/2411-6262.2017.8(4).18.

\section{For Citation}

Batyanova L. N., Borisova Yu. V., Chigrina E. V., Cornakova S. V. Legal and socioeconomic problems of territorial development: the tax aspect. Baikal Research Journal, 2017, vol. 8, no. 4. DOI : 10.17150/2411-6262.2017.8(4).18. (In Russian).

\section{Baikal Research Journal}

